\title{
Seasonal Nutrient Contents in Grey and Non-grey Flue-cured Tobacco*
}

\author{
by \\ Neville Amold \\ Researcb Branch, Agriculture Canada, L'Assomption, Quebec, Canada
}

\author{
Calvin Chong \\ Department of Plant Science, McDonald College of McGill University, \\ Ste. Anne de Bellevue, Quebec, Canada
}

and

Michael Binns

Engineering and Statistical Research Institute, Agriculture Canada, Ottawa, Ontario, Canada

\section{SUMMARY}

Analysis of leaf samples at intervals between late June and early August of 1979 and 1980 indicated lower mean concentrations of nitrogen and potassium, and higher mean concentrations of iron and manganese in grey than in non-grey (normal) tobacco. In grey tobacco, the concentrations of potassium and iron were present in deficient and toxic levels, respectively, in the majority of the samples throughout the whole sampling periods. Although symptoms on leaves resembled those of iron toxicity, changes in intensity of grey symptoms during sampling were associated with severity of potassium deficiency.

\section{ZUSAMMENFASSUNG}

Die Untersuchung von Tabakblattproben in bestimmten Zeitabstānden zwischen Ende Juni und Anfang August der Jahre 1979 und 1980 zeigte, daß graufarbener Tabak im Durchschnitt weniger Stickstoff und Kalium und mehr Eisen und Mangan enthält als nicht-

\footnotetext{
* Received: 3rd September 1985 - accepred: 23rd Jaly 1986.

Contribution No. J-1011 of the St Jean Research Station and contribution No. I-642 of the Ottawa Engineering and Statistical Research Institute.
}

grauer (normaler) Tabak. Die grauen Blattproben wiesen in der Mehrzahl bei allen Probenahmen einerseits zu geringe Werte für Kalium und andererseits toxisch hohe Werte für Eisen auf. Wenn die Symptome auf dem Blattgut auch dem Erscheinungsbild einer Eisenvergiftung entsprachen, ist doch ein Zusammenhang zu sehen zwischen ihrer im Untersuchungszeitraum zu beobachtenden Verānderung und dem Ausmaß̉ des Kaliummangels.

\section{RESUME}

L'analyse d'échantillons de feuilles de tabac prêlevés à intervalles déterminés entre la fin de juin et le début d'août en 1979 et 1980 a montré que le tabac de couleur grise contenait en moyenne moins d'azote et de potassium et davantage de fer et de manganèse que le tabac normal (non gris). Pour tous les échantillons, il s'est avéré que, dans leur grande majorité, les feuilles grises étudiêes présentaient une concentration se situant au niveau de la carence pour ce qui était du potassium, et de la toxicité pour ce qui était du fer. Bien que les symptômes observés sur les feuilles aient ressemblé à ceux causés par une toxicité en fer, l'évolution de leur intensité au cours de la durée des examens doit cependant être associée à la gravité de la carence en potassium. 


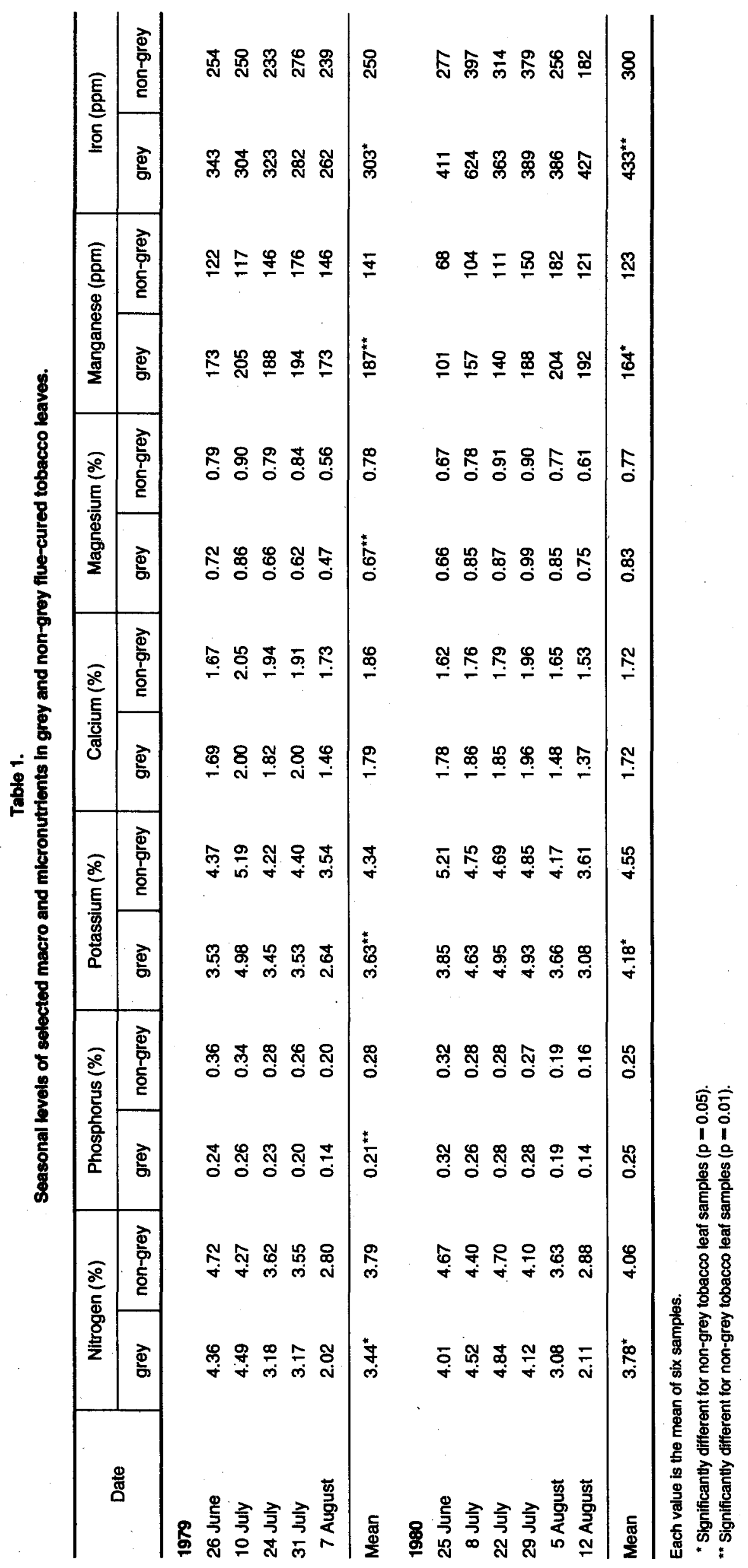




\section{INTRODUCTION}

The grey disorder of flue-cured tobacco (1) is most frequently associated with nutrient imbalance within the plant. Wide differences in the macro and micronutrient composition of grey tobacco in different growing regions or countries have been reported (18). In Quebec, where this disorder causes significant economic losses of flue-cured tobacco, ARNOLD et al. (2) reported significantly less nitrogen $(N)$, phosphorus $(P)$, potassium $(\mathrm{K})$, calcium $(\mathrm{Ca})$, and boron $(\mathrm{B})$ but more iron $(\mathrm{Fe})$ and aluminium ( $\mathrm{Al}$ ) in grey than in non-grey tobacco leaves sampled from 15 different locations. Other workers have also reported less $N(5)$ and $K(17)$ and more magnesium $(\mathrm{Mg})$, manganese $(\mathrm{Mn})$, zinc $(\mathrm{Zn})(6)$, $\mathrm{Fe}$, and chlorine $(\mathrm{Cl})(18)$ in grey tobacco.

Except for the study of ArNold et al. (2) in which fresh leaves sampled from physiologically mature plants were used, all other studies have involved cured leaves. To gain a better understanding of the nutrient status of grey tobacco during growth and development, this study compared the levels of selected macro and micronutrients in fresh leaves of grey and non-grey tobacco sampled at intervals during two growing seasons, from three locations.

\section{MATERIALS AND METHODS}

Three tobacco farms in Quebec, known to produce both grey and non-grey tobacco, were chosen for sampling in both 1979 and 1980. Soils on these farms were classified as imperfectly or well drained podzols based on survey reports of Lajoie (11), Pageau (14), and Godrout (8).

Tobacco (Nicotiana tabacum L. 'Delhi 76') was transplanted to field by 1 June and grown according to provincial recommendations. Four grey and four non-grey plants were sampled from each location at 2-week intervals between late June and late July, and subsequently at 1-week intervals until early August (Fig. 1) at which time plants were physiologically mature. At each sampling time, all leaves of four plants were bulked in pairs, oven dried, ground, and the concentration of $\mathrm{N}, \mathrm{P}, \mathrm{K}, \mathrm{Ca}, \mathrm{Mg}, \mathrm{Mn}$, and Fe determined as described by ArNold et al. (2).

The data were analysed as a series of experiments using the factorial structure: locations (L), treatments (G), and time of sampling (T) (4 (chapter 14)). For some variables, the interactions $L T$ and LG were large relative to the three-factor interaction LGT which was used to test effects.

\section{RESULTS AND DISCUSSION}

The seasonal fluctuations of $\mathrm{N}, \mathrm{P}, \mathrm{K}, \mathrm{Ca}$, and $\mathrm{Mg}$ (expressed on percentage dry weight basis) and of $M n$ and Fe (expressed in ppm dry weight basis) in leaves of grey and non-grey tobacco during the growing seasons of 1979 and 1980 are presented in Table 1. Except for $\mathrm{Ca}$ in both years, $\mathrm{Mg}$ in 1979 and $\mathrm{P}$ in 1980 only, analysis of variance indicated no significant interaction between treatments and time, but significantly lower concentrations (averaged over the season) of the macronutrients and higher concentrations of micronutrients in leaves of grey tobacco in both years.

The $\mathrm{N}$ and $\mathrm{K}$ data were further analysed by subtracting the tissue level of each nutrient element in grey from non-grey tobacco at each sampling (Table 1); results were expressed as $+\Delta$ for increases or $-\Delta$ for decreases of $\mathrm{N}$ or $\mathrm{K}$, respectively (Fig. 1). Unlike other nutrients, a consistent and similar seasonal trend in $\Delta \mathrm{N}$ and $\Delta \mathrm{K}$ levels (Fig. 1) was observed in both years. During the early growing season ( 25 or 26 June), the $\Delta N$ and $\Delta K$ levels in grey tobacco were considerably lower than in non-grey tobacco. During the midseason (10 July 1979 and 8-29 July 1980), the $\Delta N$ and $\Delta K$ levels were generally higher in grey than in non-grey tobacco. During the later growing season (24 July -7 August 1979 and 22 July -12 August 1980), the $\Delta$ levels of these elements decreased more rapidly and progressively in grey tobacco with each weekly sampling. Coincident with this trend, symptoms of grey tobacco, i.e. spotting (speckling) and chlorosis (1) on the first true leaves,

\section{Flgure 1.}

Seasonal increase $(+\Delta)$ or decrease $(-\Delta)$ in nitrogen and potasslum contents of grey compared with non-grey tobacco leaf samples (vertical bars represent standard errors).
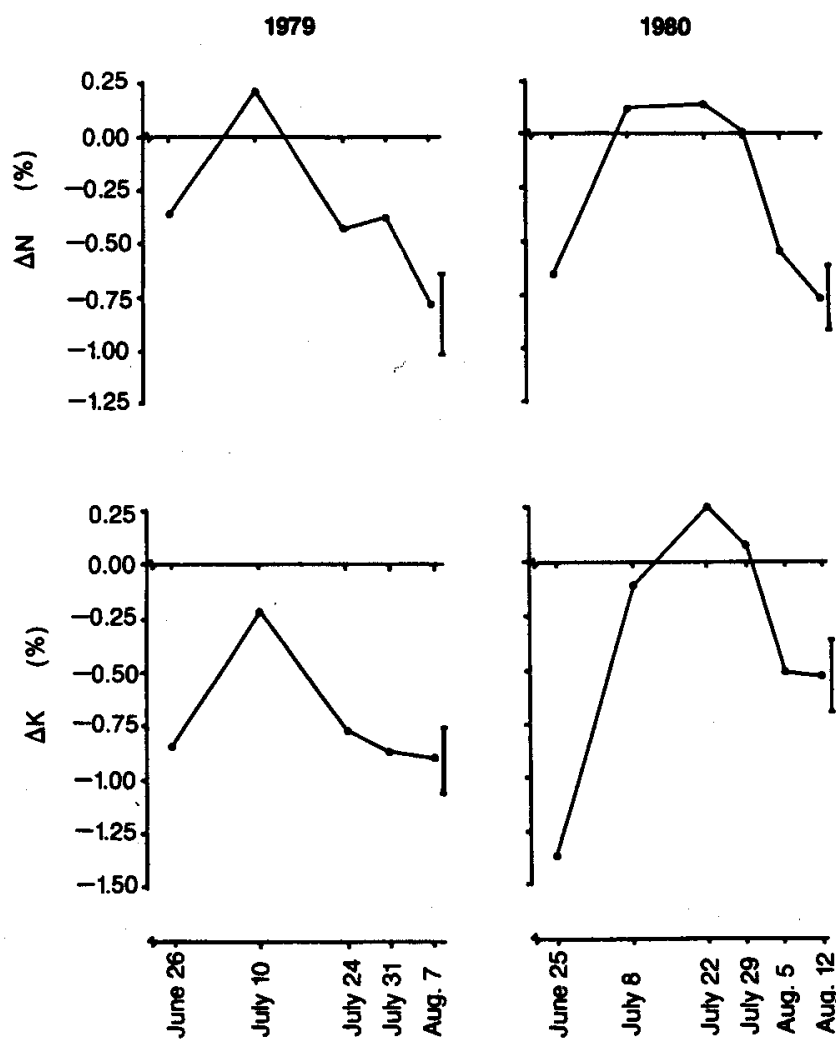
first appeared about three weeks after transplanting (first leaf sampling: 25 or 26 June (Fig. 1)). Symptoms were no longer evident in grey plants after these leaves abscised 4 or 5 days later until after 8 or 10 July sampling dates, when symptoms reappeared, starting with the leaf tips. Chlorosis apparently similar to that described for symptoms of $\mathrm{N}$ deficiency (16) was also present. Although initially not apparent in upper leaves, grey symptoms developed acropetally after each successive sampling, occurring in the uppermost leaves by the final sampling date in August of each year.

Based on reports indicating (a) that flue-cured tobacco should contain $1.5 \%$ to $2.0 \% \mathrm{~N}$ in cured leaves (12), (b) that slaty-grey tobacco, a related disorder in Rhodesia, was deficient in $N(1.35 \%)(17)$, and (c) that grey tobacco in Ontario was not excessively low in $\mathrm{N}$ $(1.54 \%-2.15 \%)(5)$, it appears that grey tobacco in the present study was not deficient in $\mathrm{N}$ although the concentration was generally less than in non-grey tobacco (Table 1 and Fig. 1). However, on the basis of similar evidence for $\mathrm{K}$ (deficiency, $2.79 \%-3.70 \%$; adequate, $4.37 \%-5.29 \%)(10)$, it appears that $K$ content in grey tobacco leaves was deficient on all dates of sampling in 1979 and 1980 , except $10 \mathrm{July} 1979$, and 8, 22 and 29 July 1980 (Table 1). These dates correspond to periods with the highest $\Delta K$ contents (Fig. 1), suggesting that $\Delta \mathrm{K}$ contents, and possibly also those of $\Delta N$, are related with appearance or intensity of grey tobacco symptoms. In slaty-grey tobacco, a related disorder described in Rhodesia, WILTSHIRE (17) implicated both low $\mathrm{N}$ and $\mathrm{K}$ as causal factors. The evidence also suggests that a split application of $\mathrm{K}$ fertilizer once in spring and again in midseason may alleviate the grey disorder, but further studies are required to clarify this view,

Both $\mathrm{Fe}$ and $\mathrm{Mn}$ levels in grey tobacco were consistently higher than in non-grey tobacco throughout the two growing seasons. Based on reports indicating a level of about $300 \mathrm{ppm} F e$ in grey tobacco $(6,15)$, the levels of $\mathrm{Fe}$ analysed in tobacco leaf samples collected during the growing season of both years were generally within or above this toxic range. At no time did the $\mathrm{Mn}$ content approach toxic levels of $3000 \mathrm{ppm}$ suggested by BORTNER (3) or $4000 \mathrm{pPm}$ to $11000 \mathrm{ppm}$ suggested by JACOBSON and SwANBACK (9). This evidence supports previous observations of ARNOLD et al. (2) indicating that symptoms of Quebec grey tobacco resembled more closely those of $\mathrm{Fe}$ toxicity rather than those caused by excess Mn or Al. According to GAYED (7), grey tobacco in the field is mainly caused by Mn toxicity and is more common in acidic soil where $\mathrm{Mn}$ is absorbed faster by the plant. No difference was observed in the $\mathrm{pH}$ of grey and non-grey soils in Quebec (2). However, Mn cannot be entirely ruled out as a causative agent in grey tobacco because $\mathrm{Mn}$ and $\mathrm{Fe}$ are closely interrelated in their metabolic functions with the effectiveness of one element determined by the proportionate presence of the other (13).

This study confirms that symptoms of grey tobacco on leaves seemed most closely associated with $\mathrm{Fe}$ toxicity and also suggests a relationship between severity of $\mathrm{K}$ deficiency and intensity of grey tobacco symptoms.

\section{REFERENCES}

1. Arnold, N. P.: Grey flue-cured tobacco in Quebec; Canadex 181.532, Agriculture Canada, 1983.

2. Arnold, N., C. Chong and M. Binns: A comparative study of the mineral nutrients in grey and nongrey flue-cured tobacco; Can. J. Plant Sci. 61 (1981) $703-710$.

3. Bortner, C. E.: Toxicity of manganese to Turkish tobacco in acid Kentucky soils; Soil Sci. 39 (1935) $15-33$.

4. Cochran, W. G., and G. M. Cox: Experimental designs; John Wiley \& Sons, Inc., New York, N.Y., 1968.

5. Elliot, J. M., and M. E. Back: A preliminary study of grey tobacco in Ontario; Tob. Sci. 7 (1963) 105-109.

6. Elliot, J. M., and B. J. Finn: The influence of manganese, iron, calcium, phosphorus, and chlorine on the occurrence and chemical composition of grey tobacco in Ontario; Tob. Sci. 10 (1966) 35-40.

7. Gayed, S. K.: Tobacco diseases; Agric. Can. Publ. $1641,1978$.

8. Godbout, G.: Etude pédologique du comté de Berthier, Ministère de l'Agriculture, Province de Québec; Bull. Tech. No. 5, 1957.

9. Jacobson, H. G. M., and T. R. Swanback: Manganese content of certain Connecticut soils and its relation to the growth of tobacco; Agron. J. 24 (1932) 237-245.

10. Lagatu, $H$., and L. Maume: Variations des rapports physiologiques en corrélation avec la maladie du feu sauvage chez la feuille de tabac; C.R. Acad. Sci. 201 (1935) 374-376.

11. Lajoie, P. G.: Etude pédologique des comtés de l'Assomption et de Montcalm; Ministère de l'Agriculture du Canada, 1965.

12. Mason, J. Y., and M. T. Lea: Evaluation of tobacco; 9th Tobacco Chemists' Research Conference, North Carolina State College, Raleigh, N.C., 1955.

13. Olsen, R, A, J. C. Brown, J. H. Bennett and D. Blume: Reduction of $\mathrm{Fe}$ as it relates to $\mathrm{Fe}$ chlorosis; J. Plant Nutr. 5 (1982) 433-445.

14. Pageau, E.: Etude pédologique du comté de Joliette, Ministère de l'Agriculture, Province de Québec; Bull. Tech. No. 8, 1961.

15. Shinohara, T., T. Okamura, K. Eguchi and H. Kitano: Studies on the grey leaf of flue-cured tobacco, I. The occurrence of grey tobacco and cultural and other environmental conditions in the tobacco growing areas; Okay Tabaka Shikenjo 41 (1980) 17—28.

16. Sprague, H. B.: Hunger signs in crops; Davis Mckay Co., New York, N.Y., 1964. 
17. Wiltshire, G. H.: Clues in the search for the causes of slaty leaf; Tob. Forum of Rhodesia No. 20, 1966, 14-15.

18. Wood, D. J.: Grey tobacco - Certain factors which contribute to this colour defect; $21 \mathrm{st}$ Tobacco Chemists' Research Conference, Durham, N.C., 1967. (Copy obtainable from author, BritishAmerican Tobacco Co. Ltd., Regent's Park Road, Southampton, England.)

\section{Acknowledgement}

The authors wish to acknowledge the technical assistance of Mr. Raymond Pellerin, Experimental Farm, L'Assomption, Que.
Addresses of authors:

Dr. Neville Amold,

Research Branch,

Agriculture Canada,

801, route 344,

P.O. Box 1070,

L'Assomption, Que., JOK 1GO, Canada.

Dr. Calvin Cbong,

at present:

Horticultural Research Institute of Ontario,

Ministry of Agriculture and Food,

Vineland Station, Ont., LOR 2EO, Canada.

Dr. Michael Binns,

Engineering and Statistical Researcb Institute, Agriculture Canada,

Ottawa, Ontario, K1A 0C6, Canada. 